\title{
Activation of epidermal growth factor receptor is responsible for pervanadate-induced phospholipase $D$ activation
}

\author{
Young-Rae Kim', Hyun-Young Cha', \\ Kyu Lim ${ }^{1}$, Byung-Doo Hwang ${ }^{1}$, \\ Kwang-Lae $\mathrm{Hoe}^{2}$, Uk Namgung ${ }^{3}$ and \\ Seung-Kiel Park ${ }^{1,4}$
}

\author{
Department of Biochemistry, College of Medicine \\ Chungnam National University, Daejeon 301-130, Korea \\ ${ }^{2}$ Genome Research Center \\ Korea Research Institute of Bioscience and Biotechnology \\ Daejeon 305-333, Korea \\ ${ }^{3}$ Department of Oriental Medicine \\ Daejeon University, Daejeon 300-716, Korea \\ ${ }^{4}$ Corresponding author: Tel, 82-42-580-8224; \\ Fax, 82-42-580-8121; E-mail, parksk@cnu.ac.kr
}

Accepted 16 April 2003

Abbreviations: EGFR, epidermal growth factor receptor; ERK, extracellular signal-regulated kinase; JNK, C-Jun $\mathrm{NH}_{2}$-terminal kinase; MAPK, mitogen-activated protein kinase; PLD, phospholipase D; PtdBut, phosphatidylbutanol; ROS, reactive oxygen species

\begin{abstract}
Pervanadate, a complex of vanadate and $\mathrm{H}_{2} \mathrm{O}_{2}$, has an insulin mimetic effect, and acts as an inhibitor of protein tyrosine phosphatase. Pervanadate-induced phospholipase $D$ (PLD) activation is known to be dependent on the tyrosine phosphorylation of cellular proteins and protein kinase C (PKC) activation, and yet underlying molecular mechanisms are not clearly understood. Here, we investigated the signaling pathway of pervanadate-induced PLD activation in Rat2 fibroblasts. Pervanadate increased PLD activity in dose- and timedependent manner. Protein tyrosine kinase inhibitor, genistein, blocked PLD activation. Interestingly, AG-1478, a specific inhibitor of the tyrosine kinase activity of epidermal growth factor receptor (EGFR) blocked not only the PLD activation completely but also phosphorylation of p38 mitogenactivated protein kinase (MAPK). However, AG1295, an inhibitor specific for the tyrosine kinase activity of pletlet drived growth factor receptor (PDGFR) did not show any effect on the PLD activation by pervanadate. We further found that pervanadate increased phosphorylation levels of
\end{abstract}

p38, extracellular signal-regulated kinase (ERK) and c-Jun $\mathrm{NH}_{2}$-terminal kinase (JNK). SB203580, a p38 MAPK inhibitor, blocked the PLD activation completely. However, the inhibitions of ERK by the treatment of PD98059 or of JNK by the overexpression of JNK interacting peptide JBD did not show any effect on pervanadate-induced PLD activation. Inhibition or down-regulation of PKC did not alter the pervanadate-induced PLD activation in Rat2 cells. Thus, these results suggest that pervanadate-induced PLD activation is coupled to the transactivation of EGFR by pervanadate resulting in the activation of p38 MAP kinase.

Keywords: mitogen-activated protein kinases; phospholipase D; proto-oncogene protein pp60 (c-src); receptor, epidermal growth factor; vanadates

\section{Introduction}

Hydrolysis of membrane phosphatidylcholine by phospholipase $D$ (PLD) has been recognized as a mechanism of signal transduction in mammalian cells (Exton, 1997; Liscovitch et al., 2000). PLD can be activated by stimulation of G-protein coupled receptors, receptor tyrosine kinases, cytokines and reactive oxygen species (ROS). PLD activity is believed to be involved in vesicle transport, proliferation and death (Kim et al., 2003).

Reactive oxygen species such as hydrogen peroxide $\left(\mathrm{H}_{2} \mathrm{O}_{2}\right)$ and superoxide is recognized as a second messenger (Bae et al., 1997). It was reported that the level of cellular protein tyrosine phosphorylations increases by oxidative stress by $\mathrm{H}_{2} \mathrm{O}_{2}$ and is strongly potentiated by addition of vanadate (Heffetz et al., 1990). The underlying molecular mechanism involves the inhibitions of protein-tyrosine phosphatase (Heffetz et al., 1990) or increased tyrosine kinase activity (Koshio et al., 1988) or both. Pervanadate promotes insulin receptor tyrosine phosphorylation by inhibiting phosphotyrosine phosphatase associated with the insulin receptor (Swarup et al., 1982). Furthermore, pervanadate activates signal transducer and activator of transcription (STAT) proteins (Ruff et al., 1997), extracellular signal-regulated kinase (ERK) (Gudmundsdottir et al., 2001; Natarajan et al., 2001), p38 (Gudmundsdottir et al., 2001; Natarajan et al., 2001), c-Jun $\mathrm{NH}_{2}$-terminal kinase (JNK) (Gudmundsdottir et al., 2001; Natarajan et al., 2001), and phos- 
pholipase D (Natarajan et al., 2001).

Upon binding of specific ligand, EGFR undergoes dimerization and activation of its intrinsic tyrosine kinase activity. These events lead to the autophosphorylation of multiple tyrosine residues in the $\mathrm{COOH}$ terminal tail of the molecule that serve as binding sites for cytosolic signaling proteins containing Src homology $2(\mathrm{SH} 2)$ domains and phosphotyrosine binding domains (Hackel et al., 1999). EGFR also participates in the signaling networks transactivated by stimuli that do not directly interact with this receptor. This transactivation occurs by agonists that specifically bind to other membrane receptors, membrane depolarization agents, and environmental stressors (Carpenter et al., 1999). Cellular Src functions as a co-transducer of transmembrane signals emanating from a variety of growth factor receptors, including EGFR (Luttrell et al., 1988). Evidence indicates that EGFR and the nonreceptor tyrosine kinase Src cooperate in both mitogenesis and transformation (Luttrell et al., 1988).

Pervanadate stimulates PLD activity by $G$ proteinindependent (Bourgoin and Grinstein, 1992), or G protein-dependent (Dubyak et al., 1993) mechanisms or p38 MAPK dependent manner (Natarajan et al., 2001; Min et al., 2002). In response to stimulation by pervanadate, PLD1 was tyrosine-phosphorylated and associated with several undefined, tyrosine-phosphorylated proteins in HL-60 cell (Marcil et al., 1997). p38 MAPK and Src are associated with PLD and involved in pervanadate-induced PLD activation in endothelial cells (Natarajan et al., 2001; Parinandi et al., 2001). However, the upstream event mediating p38-dependent PLD activation by pervanadate was not determined. Here, we demonstrate for the first time that the transactivation of EGFR is involved in pervanadate-induced PLD activation in Rat2 cells through p38 MAPK activation.

\section{Materials and Methods}

\section{Materials}

FBS, Hepes-buffered DMEM with L-glutamine, penicillin and streptomycin were purchased from Life Technologies (Rockville, MD). Sodium orthovanadate, hydrogen peroxide and PMA were from Sigma (St. Louis, MO). Pervanadate was prepared by mixing 1 $\mathrm{ml}$ of $100 \mathrm{mM} \mathrm{H}_{2} \mathrm{O}_{2}$ with $1 \mathrm{ml}$ of $100 \mathrm{mM} \mathrm{Na} \mathrm{VO}_{4}$. Anti-PLD antibody was a generous gift from Dr. Ryu, S.H. (Pohang University, Korea). Antibodies against phospho-ERK, phospho-JNK and phospho-p38 were from Cell Signaling (Beverly, MA). $\left[9,10-{ }^{3} \mathrm{H}\right]$ Myristic acid $(10 \mathrm{Ci} / \mathrm{mmol})$ was purchased from DuPont NEN. Ro31-8220 was from Roche. SB203580, PD98059, $A G 1295, P P 2, A G 1478$ and GF109203X were from CalBiochem (La Jolla, CA). Nitrocellulose filter and
ECL detection kit were from Amersham. Reagents for protein assay were from BioRad (Hercules, CA). Silica gel 60 plate was from Whatman. Phosphatidylbutanol (PtdBut) was a generous gift from Dr. M. U. Choi (Seoul National University, Korea).

\section{Cell culture}

Rat-2 fibroblast cells were cultured in Hepes-buffered DMEM supplemented with $4 \mathrm{mM}$ L-glutamine, $10 \%$ (v/v) FBS, 100 units $/ \mathrm{ml}$ of penicillin, and $100 \mu \mathrm{g} / \mathrm{ml}$ of streptomycin at $37^{\circ} \mathrm{C}$ in a humidified, $\mathrm{CO}_{2}$-controlled $(5 \%)$ incubator. For all experiments, cells were grown to $70-80 \%$ of confluency.

\section{Cell stimulation and PLD assay}

PLD activity was determined by measuring the formation of phosphatidylbutanol (PtdBut), a reaction product of PLD in the presence of $n$-butanol. Rat- 2 cells $\left(2 \times 10^{5}\right.$ cells per $35 \mathrm{~mm}$ plate $)$ were cultured in high glucose DMEM overnight at $37^{\circ} \mathrm{C}$ in humidified $5 \%$ $\mathrm{CO}_{2}$ incubator. Cells were starved in DMEM for $9 \mathrm{~h}$, then labeled with $\left[{ }^{3} \mathrm{H}\right]$ myristic acid $(1 \mu \mathrm{Ci} / \mathrm{ml})$ for $3 \mathrm{~h}$. Unincorporated ${ }^{3} \mathrm{H}$ ]myristic acid was removed by washing with PBS, and cells were incubated in $3 \mathrm{ml}$ of PBS for $1 \mathrm{~h}$. Butanol was then added to a final concentration of $0.3 \%$ ( $\mathrm{vol} / \mathrm{vol})$. After $10 \mathrm{~min}$, cells were treated with genistein, PP2, AG1478, AG1295, PD98059, or SB203580, and stimulated with pervanadate or PMA. Cells were then incubated for time period as indicated in Figures. Radioactivities incorporated into total phospholipids and PtdBut were measured. The data were presented as a PtdBut per total count.

\section{Immunoblot analysis}

Cells were lysed with $20 \mathrm{mM}$ Hepes (pH 7.2) containing $1 \%$ Triton $\mathrm{X}-100,1 \%$ sodium deoxycholate, $10 \%$ glycerol, $150 \mathrm{mM} \mathrm{NaCl}, 50 \mathrm{mM} \mathrm{NaF}, 1 \mathrm{mM}$ $\mathrm{Na}_{3} \mathrm{VO}_{4}, 10 \mu \mathrm{g} / \mathrm{ml}$ leupeptin, $10 \mu \mathrm{g} / \mathrm{ml}$ aprotinin, and $1 \mathrm{mM}$ PMSF. Cell lysates were boiled for $5 \mathrm{~min}$ in SDS sample buffer and subjected to $10 \%$ SDS-polyacrylamide gel electrophoresis. Proteins were transferred to a nitrocellulose membrane, and blots were incubated for $30 \mathrm{~min}$ with $20 \mathrm{mM}$ Tris $(\mathrm{pH} \mathrm{7.6)}, 150$ $\mathrm{mM} \mathrm{NaCl}$, and $0.1 \%(\mathrm{v} / \mathrm{v})$ Tween-20 containing $5 \%$ $(w / v)$ nonfat dried milk. The membrane was incubated with antibodies recognizing ERK, p38, phosphorylated ERK or phosphorylated p38. Blots were washed in $20 \mathrm{mM}$ Tris ( $\mathrm{pH} 7.6), 150 \mathrm{mM} \mathrm{NaCl}$, and $0.1 \%$ $(\mathrm{v} / \mathrm{v})$ Tween-20. Depending on the origin of the primary antibodies, anti-mouse or anti-rabbit $\lg G$ antibodies coupled with horseradish peroxidase were used for detection of corresponding proteins using enhanced chemiluminescence reagent. 


\section{JNK assay}

Cells were washed with cold PBS and lysed in kinase lysis buffer $(20 \mathrm{mM}$ Tris- $\mathrm{HCl}, \mathrm{pH} 7.4,25 \mathrm{mM} \beta-$ glycerophosphate, $2 \mathrm{mM}$ sodium pyrophosphate, 1 $\mathrm{mM} \mathrm{Na} \bigvee_{3} \mathrm{VO}_{4}, 2 \mathrm{mM}$ EDTA, $0.5 \mathrm{mM}$ dithiothreitol, 50 $\mu \mathrm{g} / \mathrm{ml}$ leupeptin, $50 \mu \mathrm{g} / \mathrm{ml}$ aprotinin and $1 \mathrm{mM}$ PMSF). The $200 \mu \mathrm{g}$ protein of cell extract and $10 \mu \mathrm{g}$ GSTc-Jun protein were mixed and incubated in kinase reaction buffer $(25 \mathrm{mM}$ Hepes, $\mathrm{pH} 7.4,1 \mathrm{nM}$ ATP, $25 \mathrm{mM}$ ß-glycerophosphate, $25 \mathrm{mM} \mathrm{MgCl}, 0.1 \mathrm{mM}$ $\mathrm{Na}_{3} \mathrm{VO}_{4}, 0.5 \mathrm{mM}$ dithiothreitol, I mM PMSF containing $\left.10 \mu \mathrm{Ci}\left[\gamma^{32} \mathrm{P}\right] \mathrm{ATP}\right)$ for $30 \mathrm{~min}$ at $30^{\circ} \mathrm{C}$. Following incubation, the reaction was stopped by addition of $4 \times$ Laemmli's sample buffer followed by boiling. The samples were resolved by electrophoresis, and phosphorylation levels of GST-c-Jun were determined by autoradiography.

\section{Results}

\section{Pervanadate-induced PLD activation in Rat-2 cell is dependent not on PKC but protein tyrosine phosphorylation}

Treatment of Rat2 cells with $1 \mathrm{mM}$ pervanadate activated PLD in a time-dependent manner (Figure $1 \mathrm{~A}$ ) and PLD activity was increased in a dose-dependant manner reaching maximal activation at $1 \mathrm{mM}$ pervanadate (Figure 1B). Rat2 cells did not show any effect up to $5 \mathrm{mM} \mathrm{H}_{2} \mathrm{O}_{2}$ (data not shown). Since pervanadate greatly induced tyrosine phosphorylation of cellular proteins (Figure 2A), the involvement of protein tyrosine kinase was examined in a pervanadate-mediated PLD activation. Pretreatment of cells with genistein, a general protein tyrosine kinase inhibitor, and an antioxidant NAC blocked pervanadateinduced PLD activation in a concentration dependent manner (Figure 2B, C). Possible involvement of PKC activity was also checked in pervanadate-induced PLD activation. PKC inhibitors GF-109203X and Ro$31-8220$ induced slight increase in pervanadate-induced PLD activation (Figure 3) while blocking PMAinduced PLD activation completely (data not shown). These results are in contrast to an earlier report of Min et al. (2002). Moreover, down-regulation of PKC by prolonged treatment of PMA did not inhibit the pervanadate-induced PLD activation. These results demonstrate that protein tyrosine kinase, but not PKC is involved in pervanadate-induced PLD activation in Rat2 cells.

\section{Pervanadate-induced PLD activation involves EGFR and Src tyrosine kinase activity}

Cellular stresses such as $\mathrm{H}_{2} \mathrm{O}_{2}$, UV and osmotic shock can activate growth factor receptors to maintain a
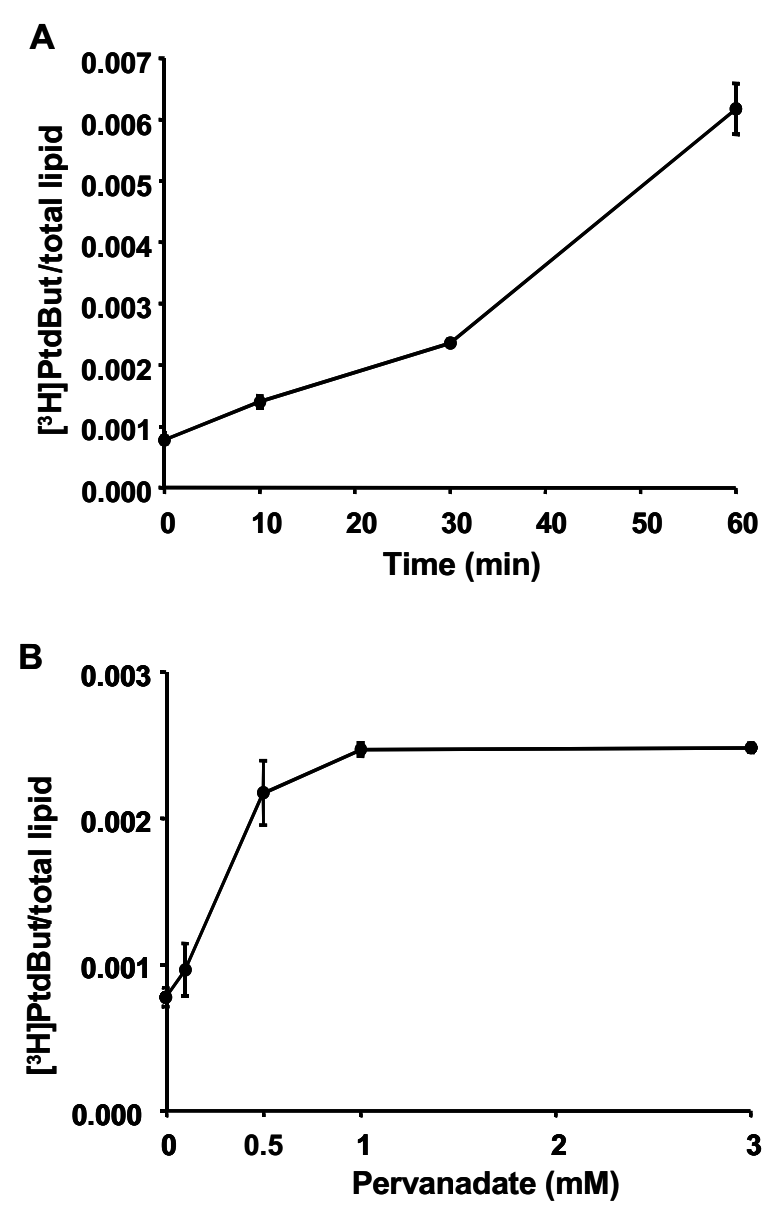

Figure 1. Time- and dose-dependence of pervanadate-stimulated PLD activation in Rat-2 cells. Serum-starved Rat2 cells were stimulated with $1 \mathrm{mM}$ pervanadate for the indicated times $(\mathrm{A})$ or with various concentrations of pervanadate for $30 \mathrm{~min}(B)$. The radioactivity incorporated into PtdBut was measured. Data represent means \pm SEM of three separate experiments.

homeostatic cellular environment and consequential cellular signaling (Carpenter, 1999). Possible involvement of EGFR was explored in pervanadate-induced PLD activation. Pretreatment of Rat2 cells with EGFR tyrosine kinase inhibitor, AG-1478 showed attenuation of PLD activation by pervanadate in a dose-dependent manner (Figure 4A). However, AG-1295 a specific PDGF inhibitor did not show any effect on the PLD activation.

In addition, an antioxidant NAC blocked the tyrosine phosphorylation of EGFR (Figure 2D), but $\mathrm{H}_{2} \mathrm{O}_{2}$ did not (data not shown). Src is known to transactivate EGFR, and also involved in PLD activation. Pretreatment of cells with PP-2, a specific Src inhibitor resulted in complete inhibition of pervanadateinduced PLD activation (Figure 4B). These data suggest that pervanadate-induced stimulation of PLD activity was likely mediated through the transactivation of EGFR and Src activation. 
A

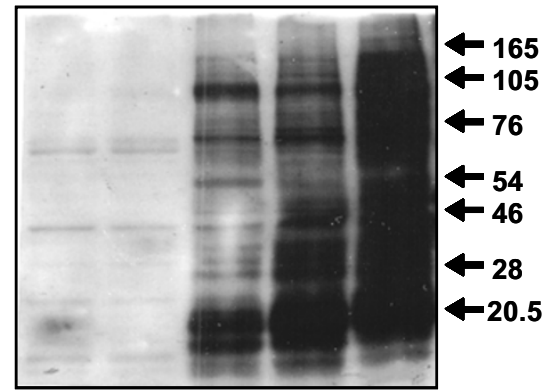

Pervanadate (mM): 0

$0.1 \quad 0.5 \quad 1$
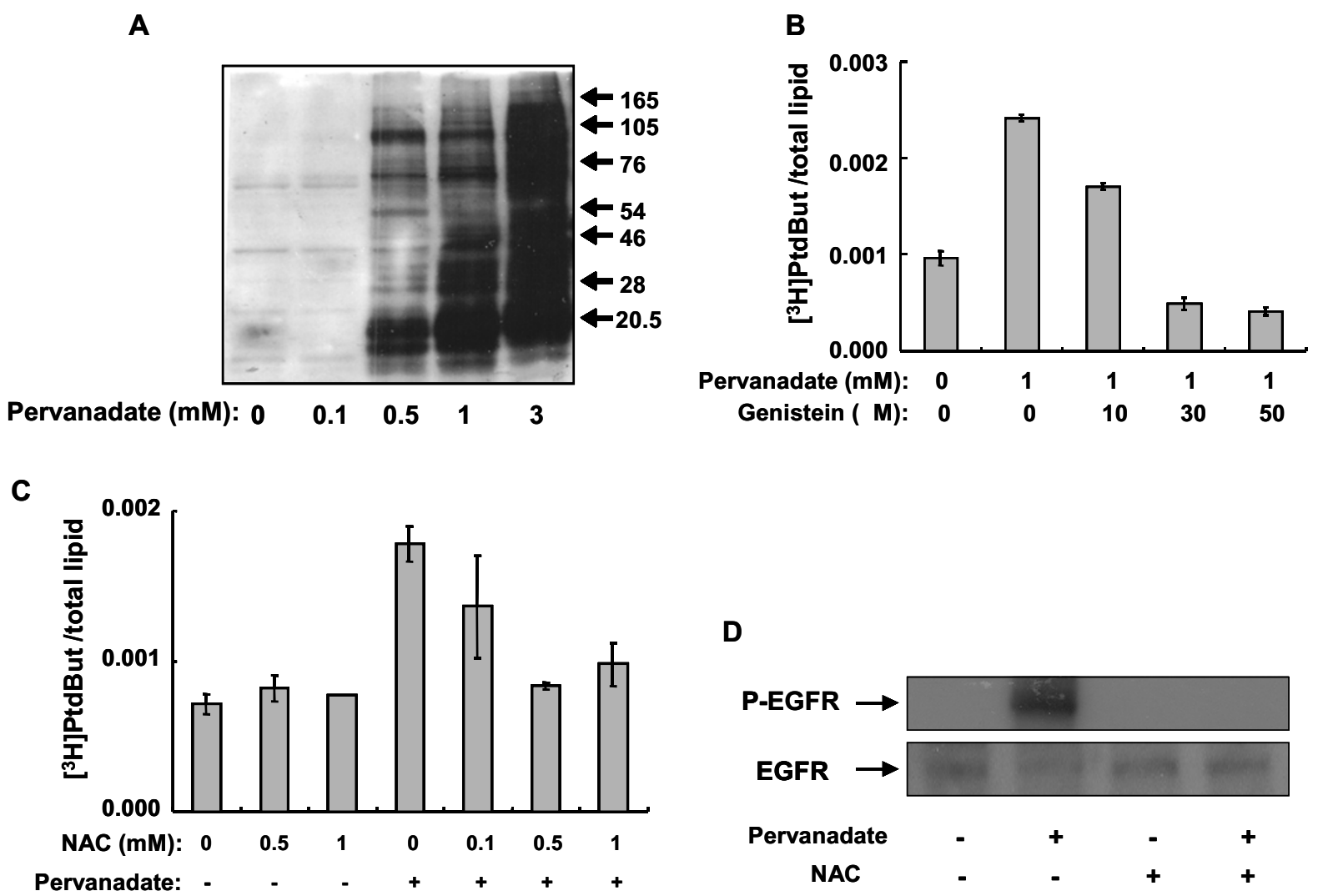

D

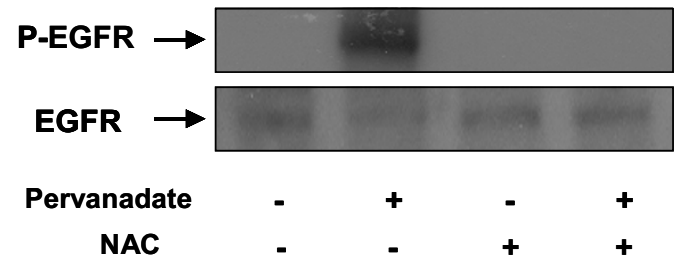

Figure 2. Effects on pervanadate-stimulated PLD activations by tyrosine kinase inhibitor and antioxidant. Serum-starved Rat-2 cells were treated with various concentrations of pervanadate. Protein tyrosine phosphorylations of cellular proteins were probed with anti-phosphotyrosine antibody (4G10) (A). Also, inhibitions of pervanadate-induced PLD activation by genistein (B) or antioxidant $\mathrm{N}$-acetylcysteine (C) were investigated in the presence or the absence of One millimolar pervanadate for $30 \mathrm{~min}$. D: The phosphorylation of EGFR was assayed by Western blotting with anti- phospho-EGFR (Y1173) antibody. One millimolar $\mathrm{N}$-acetylcysteine was pretreated to Rat2 cells for $30 \mathrm{~min}$, and then $1 \mathrm{mM}$ pervanadate was treated for 30 min. The radioactivity incorporated into PtdBut was measured. Data represent means \pm SEM of three independent experiments.

\section{Pervanadate stimulates PLD activity through p38 activation}

Pervanadate is known to induce activations of PLD as well as MAPK. Possible singal cascade between PLD activation with MAPK was examined by using specific p38 MAPK inhibitor, SB-203580. As shown in Figure 5, pervanadate activated ERK1/2, p38, and JNK MAPK. The profiles of the p38 MAPK and PLD activations by pervanadate were very similar (compare Figure 5 with Figure 1B). Moreover, SB-203580 specifically inhibited pervanadate-induced PLD activation in a concentration dependent manner (Figure 6 A). Overexpression of dominant negative p38 MAPK inhibited pervanadate-induced PLD activation (Figure 6B). Finally, blockage of EGFR kinase activity by AG1478 attenuated p38 phosphorylation (Figure 6C) and PLD activation (Figure 4A).

However, Rat2 cells pretreated with PD98059, a specific ERK inhibitor did not affect the activation of PLD activity induced by pervanadate (data not shown). Moreover, $0.1 \mathrm{mM}$ concentration of pervanadate that

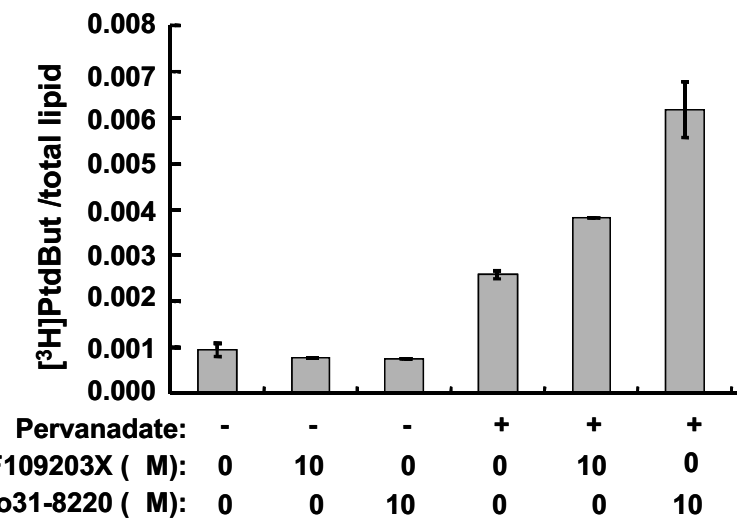

Figure 3. Effects of pervanadate on PLD activations by PKC inhibitors, GF $109203 X$ and Ro 31-8220. Serum-starved Rat-2 cells were pretreated with various concentrations of GF $109203 X$ and Ro318220 , then PLD activities were assayed by the treatment of $1 \mathrm{mM}$ pervanadate for $30 \mathrm{~min}$. The radioactivity incorporated into PtdBut was measured. Data represent the means \pm SEM of three separate experiments. 

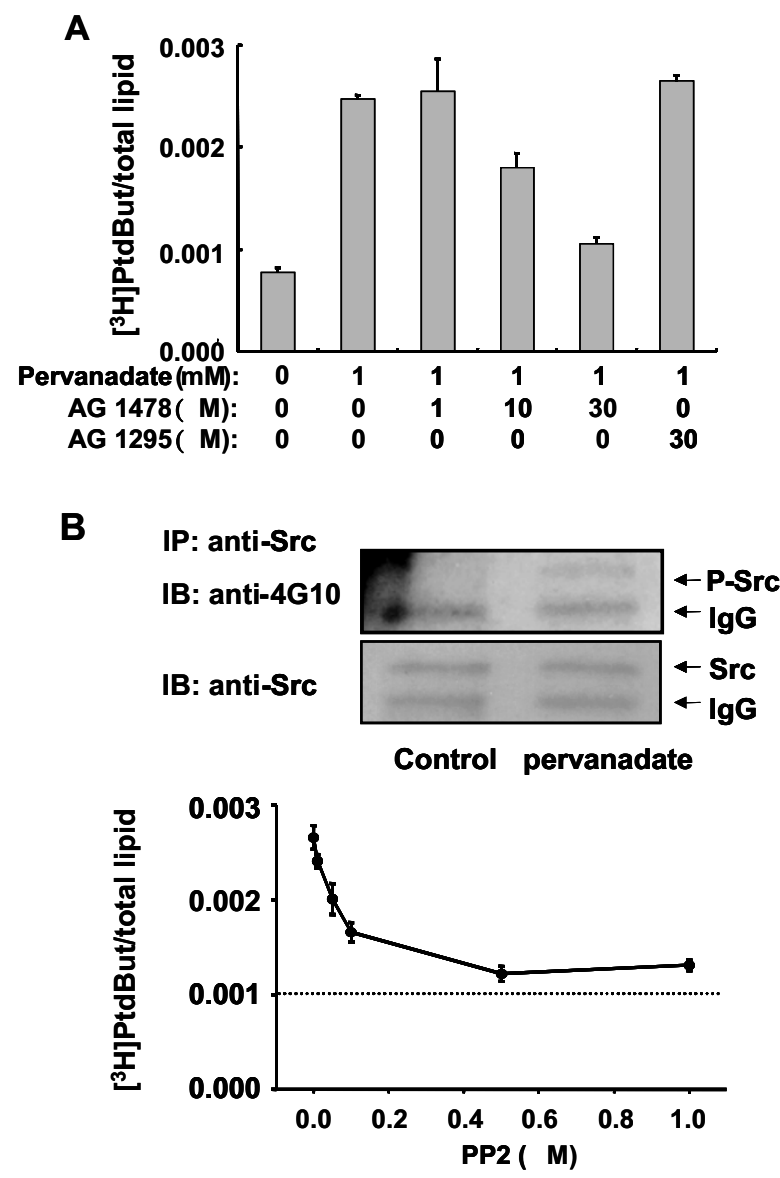

Figure 4. Regulation of pervanadate-induced PLD activity by EGFR tyrosine kinase and Src tyrosine kinase. Serum-starved Rat2 cells were treated with various concentration of AG 1478, AG 1295 (A) and PP-2 (B) for $30 \mathrm{~min}$, then stimulated with $1 \mathrm{mM}$ pervanadate for 30 min. The radioactivity incorporated into PtdBut was measured. Data represent the means \pm SEM of three separate experiments.

had no affect in PLD activation, caused maximal stimulation of ERK1/2 phosphorylations (Figure 5 and $1 \mathrm{~B}$ ), suggesting that $E R K$ is not involved in pervanadate-induced PLD activation in Rat2 cells.

Although JNK is strongly activated by pervanadate (Figure 5), pervanadate concentrations required for maximal stimulation of the PLD activity differ from those for the JNK activation. Also overexpression of $\mathrm{JBD}$, a negative regulator of JNK, did not affect the PLD activation (data not shown).

These results suggest that in Rat 2 cells, stimulation of $\mathrm{p} 38$, but not JNK or ERK kinases precedes PLD activation in the signaling pathway of EGFR transactivation by pervanadate.

\section{Discussion}

The object of the present study was to examine pos-

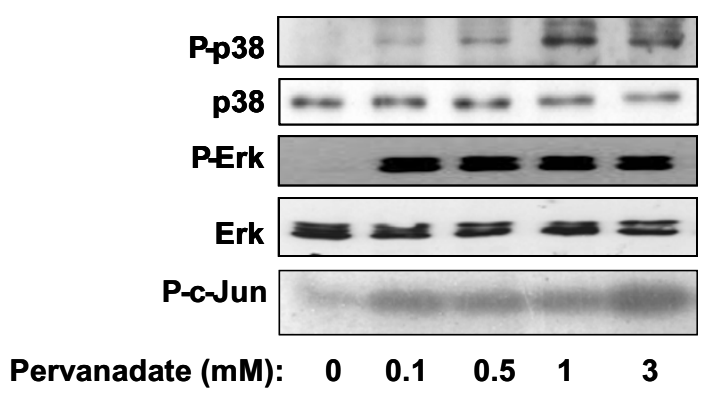

Figure 5. Pervanadate-induced PLD activation by MAPKs. Serumstarved Rat2 cells were treated with various concentrations of pervanadate for $30 \mathrm{~min}$. Phosphorylations of ERK and p38 MAPKs were determined by Western blotting with their specific antibodies. JNK activation was assessed by phosphorylation of GST-c-Jun protein. The autoradiograms shown here are the representative results of three independent experiments.

sible signaling pathway in pervanadate-mediated PLD activation. We demonstrated that pervanadate-induced PLD activation in Rat2 cells is mediated by EGFR transactivation including Src and p38 activation, not by $\mathrm{PKC}$.

$\mathrm{H}_{2} \mathrm{O}_{2}$ stimulates PLD activity in a PKC-dependent manner in leukemic L1210 cell, Swiss 3T3 fibroblast cell, pheochromocytoma PC12 cell and brain slice (Min et al., 1998; Lee et al., 2000; Oh et al., 2000; Servitja et al., 2000), and in a PKC-independent manner in bovine pulmonary artery endothelial cells (Natarajan et al., 1993). Pervanadate-induced PLD activation in HL-60 cells is mainly dependent on tyrosine phosphorylation (Bourgoin and Grinstein, 1992). In this study, we found that pervanadate-induced PLD activation in Rat- 2 cells was completely dependent on tyrosine phosphorylation pathway. Pervanadate-induced PLD activation was inhibited by the pretreatment of antioxidant, $\mathrm{NAC}$ (Figure $2 \mathrm{C}$ ), and $\mathrm{H}_{2} \mathrm{O}_{2}$ concentration required for $\mathrm{PLD}$ activation was higher than pervanadate. Although $\mathrm{H}_{2} \mathrm{O}_{2}$ and pervanadate are oxidizing agents and inhibit phosphotyrosine phosphatase, they have different effects on cells. In this study, $\mathrm{H}_{2} \mathrm{O}_{2}$ did not stimulate PLD activity and tyrosine phosphorylation of EGFR (data not shown) while pervanadate stimulated them. These results demonstrate that $\mathrm{H}_{2} \mathrm{O}_{2}$ and pervanadate have different effects on cells although they enhance tyrosine phosphorylations of proteins. Previous report showing that the activation mechanism of NF-kB activation by $\mathrm{H}_{2} \mathrm{O}_{2}$ is different from the activation mechanism by pervanadate (Krejsa et al., 1997) supports our data.

There are reports that blocking of p38 MAPK attenuates oxidant-stimulated PLD activation in endothelial cells by $30 \%$ (Natarajan et al., 2001) and PC-12 cells by $50 \%$ (Banno et al., 2001). ERK is also involved in PLD activation in PC-12 cells (Ito et al., 1997), neutrophils (Djerdjouri et al., 1999) and smooth 


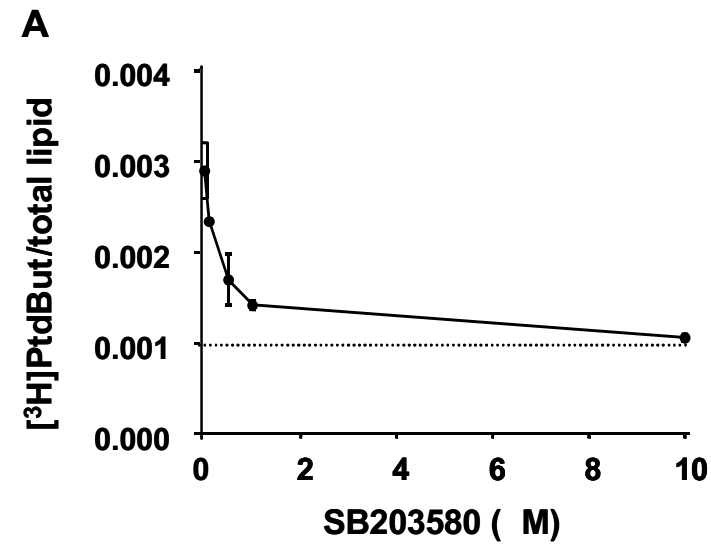

C

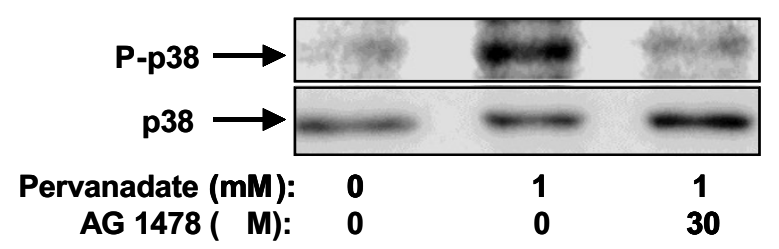

B

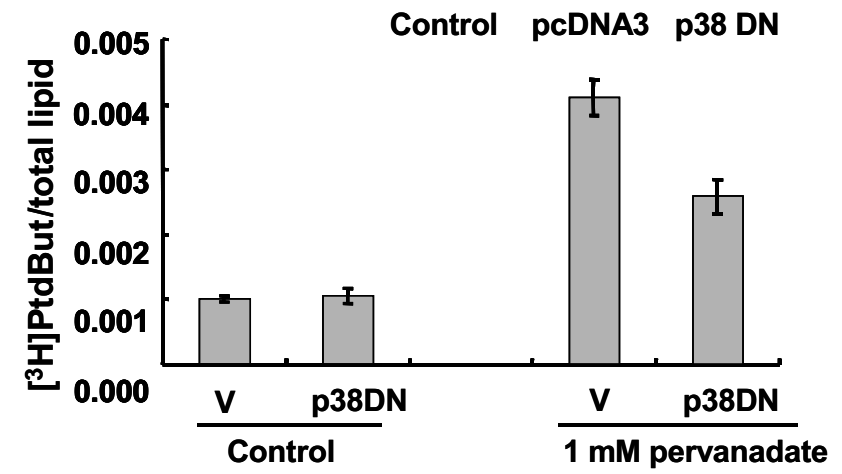

Figure 6. Involvement of the p38 MAP kinase activation in pervanadate-induced PLD activation. A, Serum starved Rat-2 cells were treated with various concentration of SB-203580 for $30 \mathrm{~min}$, then stimulated with $1 \mathrm{mM}$ pervanadate for $30 \mathrm{~min}$. B, Dominant negative mutant of p38 MAP kinase was expressed in Rat 2 cells by gene transfection, then pervanadate-induced PLD activations were measured. C, The phosphorylation of p38 MAP kinase was assayed by Western blotting with anti-phospho-p38 antibody and with anti-p38 antibody. AG 1478 was pretreated to Rat2 cells for $30 \mathrm{~min}$, and then $1 \mathrm{mM}$ pervanadate was treated for $30 \mathrm{~min}$. The radioactivity incorporated into PtdBut was measured. Data represent the means $\pm S E M$ of three independent experiments.

muscle cells (Muthalif et al., 2000). Blocking of both p38 and ERK inhibited PLD activation almost completely in PC-12 cells (Banno et al., 2001). We observed that pervanadate stimulated $\mathrm{p} 38$ and ERK strongly (Figure 5). However, p38 inhibition by SB203580 almost completely removed the pervanadateinduced PLD activation in Rat-2 cells (Figure 6A), whereas blocking of ERK or JNK by the treatment of PD98059 or expression of JBD did not. Our finding is consistent with the previous notion that activations of ERK and PLD are concurrent but independent responses to vasopressin in A7r5 cells (Jones et al., 1994). AG-1478, the specific inhibitor for EGFR kinase activity inhibited both pervanadate-stimulated p38 and PLD activation (Figure 6C and 4A). These results suggest that the transactivation of EGFR by pervanadate is coupled to PLD activation through p38 MAPK pathway.

Nonreceptor tyrosine kinase Src is implicated in nonclassical use of EGFR and stress mediated signaling (Carpenter, 1999) and also involved in PLD activation (Jiang et al., 1995). It was recently reported that $\mathrm{Src}$ is associated with pervanadate-induced PLD activation in endothelial cells (Parinandi et al., 2001). Our data demonstrating that the specific Src inhibitor
PP-2 inhibited the pervanadate-induced PLD activation (Figure 4B) are consistent with the observation in endothelial cells (Parinandi et al., 2001). Because Src is implicated in stress-activated transactivation of EGFR (Carpenter, 1999) and pervanadate-mediated PLD activation (Figure 4B), Src may be involved in pervanadate-induced PLD activation.

\section{Acknowledgement}

This work was supported by Korea Research Foundation Grant (KRF-2001-015-DP0427). We thank Dr. S. H. Ryu at Pohang University of Science and Technology and Dr. M. U. Choi at Seoul National University for a gift of antibody against to PLD and phosphatidylbutanol, respectively.

\section{References}

Bae YS, Kang SW, Seo MS, Baines IC, Tekle E, Chock PB, Rhee SG. Epidermal growth factor (EGF)-induced generation of hydrogen peroxide. Role in EGF receptor-mediated tyrosine phosphorylation. J Biol Chem 1997;272:217-21

Banno $\mathrm{Y}$, Wang $\mathrm{S}$, Ito $\mathrm{Y}$, Izumi T, Nakashima S, Shimizu 
T, Nozawa $Y$. Involvement of ERK and p38 MAP kinase in oxidative stress-induced phospholipase $D$ activation in $\mathrm{PC} 12$ cells. Neuroreport 2001;12:2271-5

Bourgoin S, Grinstein S. Peroxides of vanadate induce activation of phospholipase D in HL-60 cells. Role of tyrosine phosphorylation. J Biol Chem 1992;267:11908-16

Carpenter G. Employment of the epidermal growth factor receptor in growth factor-independent signaling pathways. J Cell Biol 1999;146:697-702

Djerdjouri B, Lenoir M, Giroud JP, Perianin A. Contribution of mitogen-activated protein kinase to stimulation of phospholipase $D$ by the chemotactic peptide fMet-Leu-Phe in human neutrophils. Biochem Biophys Res Commun 1999;264: $371-5$

Dubyak GR, Schomisch SJ, Kusner DJ, Xie MS. Phospholipase $D$ activity in phagocytic leucocytes is synergistically regulated by G-protein- and tyrosine kinase-based mechanisms. Biochem J 1993;292:121-8

Exton JH, Phospholipase D. Enzymology, mechanisms of regulation, and function. Physiol Rev 1997;77:303-20

Gudmundsdottir IJ, Halldorsson H, Magnusdottir K, Thorgeirsson $G$. Involvement of MAP kinases in the control of CPLA(2) and arachidonic acid release in endothelial cells. Atherosclerosis 2001;156:81-90.

Hackel PO, Zwick E, Prenzel N, Ullrich A. Epidermal growth factor receptors: critical mediators of multiple receptor pathways. Curr Opin Cell Biol 1999;11:184-9

Heffetz D, Bushkin I, Dror R, Zick Y. The insulinomimetic agents $\mathrm{H}_{2} \mathrm{O}_{2}$ and vanadate stimulate protein tyrosine phosphorylation in intact cells. J Biol Chem 1990;265:2896-902

Ito $Y$, Nakashima S, Nozawa Y. Hydrogen peroxide-induced phospholipase $D$ activation in rat pheochromocytoma $\mathrm{PC} 12$ cells: possible involvement of $\mathrm{Ca} 2+$-dependent protein tyrosine kinase. J Neurochem 1997;69:729-36

Jiang $\mathrm{H}$, Lu Z, Luo JQ, Wolfman A, Foster DA. Ras mediates the activation of phospholipase $D$ by $v-S r c$. J Biol Chem 1995;270:6006-9

Jones LG, Ella KM, Bradshaw CD, Gause KC, Dey M, Wisehart-Johnson AE, Spivey EC, Meier KE. Activations of mitogen-activated protein kinases and phospholipase $D$ in A7r5 vascular smooth muscle cells. J Biol Chem 1994;269: 23790-9

Kim KO, Lee KH, Kim YH, Park SK, Han JS. Anti-apoptotic role of phospholipase $D$ isozymes in the glutamate-induced cell death. Exp Mol Med 2003;35:38-45

Koshio O, Akanuma $Y$, Kasuga M. Hydrogen peroxide stimulates tyrosine phosphorylation of the insulin receptor and its tyrosine kinase activity in intact cells. Biochem J 1988; 250:95-101

Krejsa CM, Nadler SG, Esselstyn JM, Kavanagh TJ, Ledbetter JA, Schieven GL. Role of oxidative stress in the action of vanadium phosphotyrosine phosphatase inhibitors. Redox independent activation of NF-kappaB. J Biol Chem 1997; 272:11541-9
Lee BD, Kim JH, Lee SD, Kim Y, Suh PG, Ryu SH. Hydrogen peroxide-induced phospholipase $\mathrm{D} 2$ activation in lymphocytic leukemic L1210 cells. J Leukoc Biol 2000;67:630-6

Liscovitch M, Czarny M, Fiucci G, Tang, X. Phospholipase $D$ : molecular and cell biology of a novel gene family. Biochem J 2000;345:401-15

Luttrell DK, Luttrell LM, Parsons SJ. Augmented mitogenic responsiveness to epidermal growth factor in murine fibroblasts that overexpress pp60c-src. Mol Cell Biol 1988;8:497501

Marcil J, Harbour D, Naccache PH, Bourgoin S. Human phospholipase D1 can be tyrosine-phosphorylated in HL-60 granulocytes. J Biol Chem 1997;272:20660-4.

Min DS, Kim EG, Exton JH. Involvement of tyrosine phosphorylation and protein kinase $\mathrm{C}$ in the activation of phospholipase $\mathrm{D}$ by $\mathrm{H}_{2} \mathrm{O}_{2}$ in Swiss $3 \mathrm{~T} 3$ fibroblasts. $\mathrm{J}$ Biol Chem 1998;273:29986-94

Min DS, Shin EY, Kim EG. The p38 mitogen-activated protein kinase is involved in stress-induced phospholipase D activation in vascular smooth muscle cells. Exp Mol Med 2002;34:38-46

Muthalif MM, Parmentier JH, Benter IF, Karzoun N, Ahmed A, Khandekar Z, Adl MZ, Bourgoin S, Malik KU. J Pharmacol Exp Ther 2000;293:268-274

Natarajan V, Taher MM, Roehm B, Parinandi NL, Schmid $\mathrm{HHO}$, Kiss Z, Garcia JGN. Activation of endothelial cell phospholipase $D$ by hydrogen peroxide and fatty acid hydroperoxide. J Biol Chem 1993;268:930-7

Natarajan V, Scribner WM, Morris AJ, Roy S, Vepa S, Yang J, Wadgaonkar R, Reddy SPM, Garcia JGN, Parinandi NL. Role of p38 MAP kinase in diperoxovanadate-induced phospholipase D activation in endothelial cells. Am J Physiol Lung Cell Mol Physiol 2001;281:L435-49

Oh SO, Hong JH, Kim YR, Yoo HS, Lee SH, Lim K, Hwang $\mathrm{BD}$, Exton JH, Park SK. Regulation of phospholipase D2 by $\mathrm{H}(2) \mathrm{O}(2)$ in $\mathrm{PC} 12$ cells. J Neurochem 2000;75:2445-54.

Parinandi NL, Roy S, Shi S, Cummings RJ, Morris AJ, Garcia JG, Natarajan V. Role of Src kinase in diperoxovanadate-mediated activation of phospholipase $D$ in endothelial cells. Arch Biochem Biophys 2001;396:231-43

Ruff SJ, Chen K, Cohen S. Peroxovanadate induces tyrosine phosphorylation of multiple signaling proteins in mouse liver and kidney. J Biol Chem 1997;272:1263-7

Servitja JM, Masgrau R, Pardo R, Sarri E, Picatoste F. Effects of oxidative stress on phospholipid signaling in rat cultured astrocytes and brain slices. J Neurochem 2000;75: 788-94

Swarup G, Cohen S, Garbers D.L. Inhibition of membrane phosphotyrosyl-protein phosphatase activity by vanadate. Biochem Biophys Res Commun 1982;107:1104-9

Yeo EJ, Exton JH. Stimulation of phospholipase D by epidermal growth factor requires protein kinase $C$ activation in Swiss 3T3 cells. J Biol Chem 1995;270:3980-8 